\title{
Isolation of thermophilic Desulfotomaculum strains with methanol and sulfite from solfataric mud pools, and characterization of Desulfotomaculum solfataricum sp. nov.
}

\author{
Heleen P. Goorissen, ${ }^{1} \dagger$ Henricus T. S. Boschker, ${ }^{2}$ Alfons J. M. Stams ${ }^{3}$ \\ and Theo A. Hansen ${ }^{1}$ \\ ${ }^{1}$ Department of Microbiology, Groningen Biomolecular Sciences and Biotechnology Institute, \\ University of Groningen (GBB), Kerklaan 30, 9751 NN Haren, The Netherlands \\ ${ }^{2}$ Netherlands Institute of Ecology (NIOO-KNAW), Postbus 140, 4400 AC Yerseke, \\ The Netherlands \\ ${ }^{3}$ Laboratory of Microbiology, Wageningen University, Hesselink van Suchtelenweg 4, 6703 CT \\ Wageningen, The Netherlands
}

Correspondence

Heleen P. Goorissen

Heleen.Goorissen@wur.nl

\begin{abstract}
Four strains of thermophilic, endospore-forming, sulfate-reducing bacteria were enriched and isolated from hot solfataric fields in the Krafla area of north-east Iceland, using methanol and sulfite as substrates. Morphologically, these strains resembled thermophilic Desulfotomaculum species. The strains grew with alcohols, including methanol, with glucose and fructose as electron donors, and with sulfate, sulfite or thiosulfate as electron acceptors. For all four strains, the optimum temperature and $\mathrm{pH}$ for growth were $60^{\circ} \mathrm{C}$ and $\mathrm{pH} 7 \cdot 3$, respectively; no added $\mathrm{NaCl}$ was required. Phylogenetic analysis based on partial 16S rRNA gene sequence comparisons showed high levels of similarity of the novel strains (>92\%) with Desulfotomaculum kuznetsovii and Desulfotomaculum luciae. However, DNA-DNA hybridization studies with $D$. kuznetsovii revealed that the four strains belonged to one novel species. A representative of this group of isolates, strain $\mathrm{V} 21^{\top}$, is proposed as the type strain of a novel species of the spore-forming, sulfate-reducing genus Desulfotomaculum, namely Desulfotomaculum solfataricum (type strain $\mathrm{V} 21^{\top}=\mathrm{DSM}$ $14956^{\top}=$ CIP $107984^{\top}$ ).
\end{abstract}

\section{INTRODUCTION}

Thermophilic, sulfate-reducing bacteria are found in a wide range of environments including hot springs/geothermal groundwater (Zeikus et al., 1983; Daumas et al., 1988; Nazina et al., 1988; Love et al., 1993; Henry et al., 1994; Liu et al., 1997), fresh water (Elsgaard et al., 1994; Kuever et al., 1999), cold marine sediments (Isaksen et al., 1994), oilfields (Rosnes et al., 1991; Rees et al., 1995; Beeder et al., 1995; Tardy-Jacquenod et al., 1996; Nilsen et al., 1996), compost/ manure (Fardeau et al., 1995; Pikuta et al., 2000) and anaerobic bioreactors (Min \& Zinder, 1990; Tasaki et al., 1991; Weijma, 2000; Plugge et al., 2002). Most of these

tPresent address: Laboratory of Microbiology, Wageningen University, Hesselink van Suchtelenweg 4, 6703 CT Wageningen, The Netherlands.

The GenBank accession number for the 16S rRNA gene sequence of Desulfotomaculum solfataricum $\mathrm{V} 21^{\top}$ is AY084078.

A phase-contrast photomicrograph of strain $\mathrm{V} 21^{\top}$ is available in IJSEM Online. thermophiles belong to a phylogenetically coherent cluster of Gram-positive, spore-forming Desulfotomaculum species (Stackebrandt et al., 1997). Gram-negative, thermophilic, sulfate-reducing bacteria are members of the genera Thermodesulfobacterium, Thermodesulfovibrio, Thermodesulforhabdus or Desulfacinum (Henry et al., 1994; Rees et al., 1995; Rozanova et al., 2001; Sievert \& Kuever, 2000; Sonne-Hansen \& Ahring, 1999; Zeikus et al., 1983; Beeder et al., 1995). These Gram-negative sulfate-reducers are all characterized by a narrow substrate range in comparison with the thermophilic Desulfotomaculum species. Most of the thermophilic sulfate-reducers also use sulfite and thiosulfate as electron acceptors. Sulfate reduction is energetically less favourable than sulfite reduction. Sulfate has to be activated first at the expense of ATP to adenosine- $5^{\prime}$ phosphosulfate by ATP-sulfurylase; this is followed by adenosine- $5^{\prime}$-phosphosulfate reduction to sulfite and AMP (Widdel \& Hansen, 1992). Thiosulfate as electron acceptor is energetically also more favourable than sulfate, and in freshwater sediments thiosulfate is used preferentially (Jørgensen \& Bak, 1991). The aim of our work is to identify 
and characterize bacterial strains that may find application in a biological process for the thermophilic desulfurization of off-gases. For this process, thermophilic, methanolutilizing, sulfite-reducing strains were considered essential. In nature, mesophilic sulfite-reducing bacteria, i.e. Desulfitobacterium species, are found which cannot reduce sulfate (Utkin et al., 1994; Christiansen \& Ahring, 1996; Gerritse et al., 1996, 1999; Bouchard et al., 1996; Sanford et al., 1996). An appropriate sampling site for the isolation of thermophilic sulfite-reducers is the Krafla region in north-east Iceland, a relatively young, geothermically active area with recent volcanic activity. On the slopes of these young craters and in the lower region's solfataric mud pools, large differences in temperature $\left(40-110^{\circ} \mathrm{C}\right)$ and acidity $(\mathrm{pH} 2 \cdot 5-8 \cdot 0)$ were found. Enrichments from sediments of these pools led to the isolation of novel methanol-utilizing, sulfate- and sulfitereducing bacteria. In this report, we describe the isolation and characterization of strain $\mathrm{V} 21^{\mathrm{T}}$.

\section{METHODS}

Sources of cultures. Desulfotomaculum kuznetsovii DSM $6115^{\mathrm{T}}$ was purchased from the Deutsche Sammlung von Mikroorganismen und Zellkulturen (DSMZ, Braunschweig, Germany). Desulfotomaculum luciae was kindly provided by David Boone (Oregon Graduate Institute of Science and Technology, Portland, OR, USA). Strain TPOSR was isolated at the Laboratory of Microbiology in Wageningen from anaerobic methanogenic granular sludge with propionate and sulfate as substrates (A. J. M. Stams, unpublished data). Strain WW1 was enriched and isolated from a thermophilic methanol-fed, sulfatereducing, laboratory-scale reactor and was kindly provided by Jan Weijma (J. Weijma, M. Balk \& A. J. M. Stams, unpublished data). Desulfotomaculum thermobenzoicum subsp. thermosyntrophicum DSM $14055^{\mathrm{T}}$ was present in our culture collection.

Source of inocula. Sediment samples were taken from hot (45$110^{\circ} \mathrm{C}$ ) solfataric fields in the Krafla region of north-east Iceland. Around 10 samples of both the Naumaskjárd and Vití solfatares were collected from the blackened layers. Samples were kept under an anaerobic atmosphere $\left(\mathrm{N}_{2} / \mathrm{CO}_{2}, 80: 20\right)$, transported at room temperature, and used for enrichments within 7 days of sampling.

Media and cultivation. A bicarbonate-buffered medium was used for growth, enrichment, and isolation experiments. The basal medium contained the following $\left(\mathrm{g} \mathrm{l}^{-1}\right): \mathrm{NaHCO}_{3}$ (4) (separately sterilized), $\mathrm{Na}_{2} \mathrm{SO}_{4}(2 \cdot 8), \mathrm{MgCl}_{2} \cdot 6 \mathrm{H}_{2} \mathrm{O}(1 \cdot 2), \mathrm{KCl}(0 \cdot 5), \mathrm{NH}_{4} \mathrm{Cl}(0 \cdot 3), \mathrm{KH}_{2} \mathrm{PO}_{4}$ $(0 \cdot 2), \mathrm{CaCl}_{2}(0 \cdot 15)$ and $\mathrm{Na}_{2} \mathrm{~S} .7-9 \mathrm{H}_{2} \mathrm{O}(0 \cdot 3)$ (separately sterilized). The following additions were made from anoxic stock solutions and per litre of medium $0.5 \mathrm{ml}$ vitamin solution according to Stams et al. (1983): $0 \cdot 1 \mu \mathrm{M} \mathrm{Na} \mathrm{SeO}_{3}, 0 \cdot 1 \mu \mathrm{M} \mathrm{Na} \mathrm{NO}_{4}$ and $1 \mathrm{ml}$ traceelement solution SL 6, according to Pfennig \& Lippert (1966). In standard growth experiments, yeast extract $\left(1 \mathrm{~g} \mathrm{l}^{-1}\right.$; Difco $)$ and $\mathrm{NaCl}\left(7 \mathrm{~g} \mathrm{l}^{-1}\right)$ were added to the culture medium.

Enrichment and isolation. Enrichments were carried out in batch and continuous cultures. Incubations in batch experiments were done at $60{ }^{\circ} \mathrm{C}$ at neutral $\mathrm{pH}$ in $120 \mathrm{ml}$ bottles filled with $50 \mathrm{ml}$ basal medium without sulfate, then supplemented with $10 \mathrm{mM}$ methanol as electron donor, $10 \mathrm{mM}$ sulfite as electron acceptor and $5 \mathrm{mM}$ hydrogen sulfide to select for sulfide-tolerant organisms. Yeast extract was omitted. The headspace consisted of $\mathrm{N}_{2} / \mathrm{CO}_{2}(80: 20)$. Under anaerobic conditions, approximately $5 \mathrm{ml}$ sediment was added to the culture bottles. After growth was observed (4-5 weeks), sulfide production was analysed and positive cultures were transferred to fresh medium. Slow-growing organisms were enriched in a continuous culture vessel with glass and Teflon parts present. The influent contained a standard medium with $10 \mathrm{mM}$ methanol as the growthlimiting substrate, $10 \mathrm{mM}$ sulfite instead of sulfate, and $5 \mathrm{mM}$ sulfide. The dilution rate was $0.005 \mathrm{~h}^{-1}$, the temperature was $60{ }^{\circ} \mathrm{C}$, the $\mathrm{pH}$ was maintained at $7 \cdot 3$ by titration with $\mathrm{HCl}$, and the stirring speed was 100 r.p.m. At constant culture density, the culture was used for isolation. Strains were obtained in pure culture by using agar shake dilution tubes. Black colonies from the highest dilutions with growth were used for three successive transfers in agar tubes and checked for purity.

pH, temperature and $\mathrm{NaCl}$ concentration optima. The effect of $\mathrm{pH}$ on growth was determined at $60^{\circ} \mathrm{C}$. The $\mathrm{pH}$ of the basal medium was adjusted to defined values ( $\mathrm{pH}$ range $6-8 \cdot 5)$ with sterile stock solutions of $\mathrm{NaOH}$ or $\mathrm{HCl}$. The temperature range $\left(37-75^{\circ} \mathrm{C}\right)$ for growth was determined in basal medium at $\mathrm{pH} 7 \cdot 5$. The requirement for $\mathrm{NaCl}$ was determined in basal medium containing a concentration range of $0-5 \%(\mathrm{w} / \mathrm{v}) \mathrm{NaCl}$.

Electron-donor and electron-acceptor utilization. The ability of the strains to utilize substrates was tested in basal medium supplemented with autoclaved or filter-sterilized substrates. Concentrations ranged from 5 to $20 \mathrm{mM}$ and cultures were incubated for 2 weeks. The utilization of various electron acceptors was studied in basal medium containing lactate $(20 \mathrm{mM})$ as electron donor. Electron acceptors were added from sterile stock solutions to a concentration of $10 \mathrm{mM}$.

Analytical procedures. Optical density was measured at a wavelength of $660 \mathrm{~nm}$ in a Starcoll colorimeter (R\&D Mechatronics). Methanol, methane and fatty acids were analysed by GC as described previously (Heijthuijsen \& Hansen, 1989). Sulfide was determined colorimetrically using the methylene blue method of Trüper \& Schlegel (1964). Bacterial growth was determined by measuring the increase in $\mathrm{OD}_{660}$, the methanol consumption and the sulfide production.

Phospholipid fatty acid analysis. Bacterial cultures of strain $\mathrm{V} 21^{\mathrm{T}}$ and D. kuznetsovii, grown on methanol and sulfate, and D. thermobenzoicum subsp. thermosyntrophicum, grown on pyruvate and sulfate, were harvested by centrifugation $\left(20000 \mathrm{~g}, 20 \mathrm{~min}, 4^{\circ} \mathrm{C}\right)$ and pellets were directly extracted using a modified Bligh-Dyer extraction. The total lipid extract was fractionated on silic acid, and mild alkaline transmethylation was used to yield fatty acid methyl esters from the phospholipid fraction. Concentrations of individual phospholipid fatty acids as fatty acid methyl esters were determined by capillary GC coupled with a flame ionization detector. Identification of phospholipid fatty acids was based on comparison of retention-time data with known standards (see Boschker et al., 1999, for further details).

\section{Phylogenetic analysis}

Partial 16S rRNA gene sequence analysis of the four isolates. For the genotypic characterization of isolates V20, V21 ${ }^{\mathrm{T}}, \mathrm{V} 28$ and V29 and strain TPOSR, chromosomal DNA was isolated from a liquid culture as described previously (Van der Maarel et al., 1996). The 16S rRNA gene was selectively amplified by PCR, using oligonucleotide primers complementary to conserved regions of the bacterial 16S rRNA gene. The following primer pair was used: 5'-ACCTAATACGACTAC-TATAGGGAGAGTTTGATCCTGGCTCAG-3' (positions 8-27, Escherichia coli numbering) and 5'-ATTGTAAAACGACGGCCAGTGGTTACCTTGTTACGACTT-3' (positions 1492-1510, E. coli numbering). The PCR amplification products were sequenced with an Applied Biosystems 373A DNA sequencer by using the Taq DyeDeoxy terminator cycle sequencing method and custom primers based on conserved regions.

Full 16S rRNA gene sequence analysis of strain V21 ${ }^{\top}$. Extraction of genomic DNA and PCR-mediated amplification of the 
16S rRNA gene were carried out as described previously (Rainey et al., 1996). Purified PCR products were cloned using the pCRScript $\mathrm{SK}^{+}$cloning kit from Stratagene. Genomic DNA was extracted from positive clones. PCR-mediated amplification of the $16 \mathrm{~S}$ rDNA and purification of the PCR product were carried out as described previously (Rainey et al., 1996). Purified PCR products were sequenced using the ABI PRISM DYE Terminator Cycle Sequencing Ready Reaction Kit (Applied Biosystems) as directed by the manufacturer's protocol. Sequence reactions were electrophoresed using an Applied Biosystems 373A DNA sequencer. Approximately $95 \%$ of the $16 \mathrm{~S}$ rRNA gene sequence of strain $\mathrm{V} 21^{\mathrm{T}}$ was determined.

Sequence alignment and construction of a phylogenetic tree. The assembled DNA sequences were aligned with 16S rRNA gene sequences of closely related strains found in the GenBank database using CLUSTAL W. A 16S-rDNA-based phylogenetic tree was constructed from a distance matrix based on the neighbour-joining method (Saitou \& Nei, 1987), as implemented in the program TREECON (Van de Peer \& De Wachter, 1995). A manual correction method was applied and tree topology was re-examined by using bootstrap analysis (100 replications).

DNA-DNA hybridizations. DNA was isolated and purified according to Marmur (1961). The DNA base content was determined by the thermal denaturation method (Owen et al., 1961) and DNA homology was determined by De Ley's optical reassociation method (De Ley et al., 1970).

\section{RESULTS AND DISCUSSION}

\section{Isolation of pure cultures}

Two sites in the Krafla region were sampled: Naumaskjárd and Vití. Naumaskjárd is a relatively old solfataric field, although no cyanobacterial colonization was visible around the site. Samples were taken from nine solfatares ranging in temperature from 40 to $100^{\circ} \mathrm{C}$. The Vití site was on the slope of a young volcano, and elemental sulfur was abundant around this site. Samples were taken from 11 solfatares with temperatures ranging from 50 to $90{ }^{\circ} \mathrm{C}$ and $\mathrm{pH}$ values ranging from $2 \cdot 5$ to $5 \cdot 5$. Media with methanol and sulfite were inoculated with these sediments and incubated at $60^{\circ} \mathrm{C}$. After incubation for 4 weeks, sulfide was produced in three out of 20 enrichment cultures; these positive cultures all originated from inocula from the Vití sediments. No methane or acetate was produced in any of the cultures. Neither sulfide formation nor bacterial growth was observed in any of the enrichments from the Naumaskjárd field. A continuous culture inoculated with a Vití sample did produce sulfide at steady-state. Sulfide concentrations of 10-15 mM were detected and the methanol was completely used.

During the isolation procedure, the highest dilutions in which colonies were formed ranged from $10^{-5}$ to $10^{-7}$. After three successive transfers of isolated colonies to agar medium, cultures were supposed to be pure. Four strains were obtained in pure culture and designated as strains V20, $\mathrm{V} 21^{\mathrm{T}}, \mathrm{V} 28$ (isolated from batch-culture enrichments) and V29 (isolated from a continuous-culture experiment).

\section{Morphological and physiological characteristics}

Cells of all four isolates were non-motile, straight rods $(3.5-5 \times 1.5 \mu \mathrm{m})$ that were often observed in pairs or longer chains (Fig. I; supplementary data, http://ijs.sgmjournals. org). All four strains formed spores, which were spherical and central or subterminal, and sporulation caused swelling of the cells to a lemon-shaped appearance. Spores were not extremely resistant to heat sterilization, as was found for some thermophilic Desulfotomaculum strains (Goorissen, 2002). Their decimal reduction value at $120^{\circ} \mathrm{C}$ was below $3 \mathrm{~min}$. The Gram stain result was negative, as is observed often for Desulfotomaculum strains (Sleytr et al., 1969; Rosnes et al., 1991; Liu et al., 1997), but electron microscopic analysis revealed a typical Gram-positive cell wall architecture (results not shown). All four strains grew at temperatures between 48 and $65^{\circ} \mathrm{C}$, the optimum growth temperature being $60^{\circ} \mathrm{C}$. No growth was observed outside this temperature range. Growth occurred at initial $\mathrm{pH}$ values between $6 \cdot 4$ and $7 \cdot 9$. The optimal $\mathrm{pH}$ was $7 \cdot 3$. Optimal growth was observed when $\mathrm{NaCl}$ was omitted from the medium. Yeast extract stimulated growth and a vitamin supplement was required for growth.

The range of electron donors and acceptors used was similar for the four strains. The electron acceptors used were sulfate, sulfite and thiosulfate. Nitrate was not utilized. The compounds used as electron donors were as follows $(\mathrm{mM})$ : lactate (20), fumarate (10), acetate (10), formate (5), propionate (10), butyrate (10), succinate (10), $\mathrm{H}_{2} / \mathrm{CO}_{2}(80: 20$, $\mathrm{v} / \mathrm{v}$ ), glucose (20), fructose (20), ethanol (20), methanol (20), propanol (10), butanol (5) and isobutanol (5). Compounds not used were as follows $(\mathrm{mM})$ : isobutyrate (5), 3-chlorobenzoate (2), 2-propanol (5) and benzoate (5). Distinguishing features between the isolates were their $\mu_{\max }$ values on methanol $\left(0 \cdot 012-0 \cdot 034 \mathrm{~h}^{-1}\right)$ and their tolerance for $\mathrm{NaCl}(0 \cdot 7-2 \%)$. Table 1 shows characteristics of the representative strain $\left(\mathrm{V} 21^{\mathrm{T}}\right)$ in comparison with those of its closest relatives.

\section{Phospholipid fatty acid composition of bacterial cultures}

Strain $\mathrm{V} 21^{\mathrm{T}}$ contained almost exclusively only iso- $\mathrm{C}_{15: 0}$ and iso- $\mathrm{C}_{17: 0}$ as phospholipid fatty acids when cultured on methanol with sulfate (Table 2). This simple composition resembles that of Desulfotomaculum australicum (Love et al., 1993), a related strain (Table 2). The phospholipid fatty acid profiles of D. kuznetsovii and D. thermobenzoicum subsp. thermosyntrophicum were somewhat more complex, but iso$\mathrm{C}_{15: 0}$ and iso- $\mathrm{C}_{17: 0}$ were also major compounds together with $\mathrm{C}_{15: 0}$ and $\mathrm{C}_{16: 0}$ (Table 2). The fatty acid composition of D. kuznetsovii reported here was rather different from that presented by Nazina et al. (1999). Possible explanations for this difference are that Nazina et al. (1999) studied total extractable fatty acids or, more likely, that they used cultures grown on propionate with sulfate. The substrate used may influence fatty acid compositions in bacteria especially when methanol (a $\mathrm{C}_{1}$ compound) is used. 
Table 1. Characteristics of strain $\mathrm{V} 21^{\top}$ in comparison to those of its closest relatives

Strains: 1, D. kuznetsovii DSM 6115 ${ }^{\mathrm{T}}$ (Nazina et al., 1988); 2, D. luciae $\mathrm{SLT}^{\mathrm{T}}$ (Liu et al., 1997); 3, strain TPOSR (this study); 4, strain $\mathrm{V} 21^{\mathrm{T}}$ (this study). +, Weak growth; -, no growth; NR, not reported; NT, not tested. All organisms shared the following characteristics: negative Gram stain; use of formate as an electron donor; use of lactate as an electron donor; use of $\mathrm{H}_{2} / \mathrm{CO}_{2}$ as an electron donor; use of sulfate as an electron acceptor; and use of thiosulfate as an electron acceptor.

\begin{tabular}{|c|c|c|c|c|}
\hline Characteristic & 1 & 2 & 3 & 4 \\
\hline Temperature optimum $\left({ }^{\circ} \mathrm{C}\right)$ & $60-65$ & NR & $55-65$ & 60 \\
\hline Temperature range $\left({ }^{\circ} \mathrm{C}\right)$ & $50-85$ & $50-70$ & NR & $48-65$ \\
\hline Spore formation & Yes & Yes $^{*}$ & Yes & Yes \\
\hline Extremely heat-resistant spores & Yes & NT & Yes & No \\
\hline $\mathrm{NaCl}$ requirement & No & Yes & No & No \\
\hline $\mathrm{G}+\mathrm{C}$ content $(\mathrm{mol} \%)$ & 49 & $51 \cdot 4$ & 55 & $48 \cdot 3$ \\
\hline Sulfide inhibition (initial concentration, mM) & 15 & NR & 15 & 15 \\
\hline Growth factors required & No & No & NR & Vitamins \\
\hline \multicolumn{5}{|l|}{ Electron donors: } \\
\hline Glucose & - & - & - & + \\
\hline Fructose & - & NR & - & + \\
\hline Acetate & + & - & + & + \\
\hline Propionate & + & - & + & + \\
\hline Butyrate & + & - & + & + \\
\hline Fumarate & + & NR & + & + \\
\hline Succinate & + & - & + & + \\
\hline Methanol & + & - & + & + \\
\hline Butanol & NR & NR & NR & + \\
\hline Isobutanol & NR & NR & NR & + \\
\hline$\mu_{\max }$ on methanol $\left(\mathrm{h}^{-1}\right)$ & $0 \cdot 033$ & - & $0 \cdot 03$ & $0 \cdot 017$ \\
\hline \multicolumn{5}{|l|}{ Electron acceptors: } \\
\hline Sulfite & + & - & + & + \\
\hline Nitrate & - & NR & - & - \\
\hline
\end{tabular}

${ }^{\star}$ Not confirmed in this study.

\section{Phylogenetic analysis and taxonomic affiliation}

For phylogenetic screening of the strains, their partial $16 \mathrm{~S}$ rRNA gene sequences (790 bp) were compared and DNADNA homology determined. The $16 \mathrm{~S}$ rRNA gene sequence similarity between the isolates was $93 \%$. Levels of sequence similarity of up to $95 \%$ suggest that the phylogenetic distance is large enough for these strains to be designated as separate species (Stackebrandt \& Goebel, 1994). However, these sequence similarities are based on partial sequences, and the DNA-DNA homology between the strains is high, ranging from 85 to $92 \%$. The $\mathrm{G}+\mathrm{C}$ content of the DNA ranged from $48 \cdot 3$ to $48 \cdot 7 \mathrm{~mol} \%$. High levels of physiological and phylogenetic similarity between the isolates justified the choice of one strain, i.e. strain $\mathrm{V} 21^{\mathrm{T}}$, as a representative of this group of isolates. For further study and taxonomic description, strain $\mathrm{V} 21^{\mathrm{T}}$ was used as the type strain. A full $16 \mathrm{~S}$ rRNA gene sequence of strain $\mathrm{V} 21^{\mathrm{T}}$ was obtained and compared with sequences of all other described Desulfotomaculum species. The topology of the resulting phylogenetic tree (Fig. 1) is in accordance with data published by others (Nilsen et al., 1996; Liu et al., 1997; Stackebrandt et al., 1997; Pikuta et al., 2000). In the phylogenetic tree, strain $\mathrm{V} 21^{\mathrm{T}}$ consistently branches together with members of the genus Desulfotomaculum of subcluster IC. The closest relatives are D. kuznetsovii ( $93 \%$ similarity), D. luciae ( $92 \%$ similarity) and strain TPOSR ( $92 \%$ similarity). DNA-DNA hybridization studies with strain $\mathrm{V} 21^{\mathrm{T}}$ and $D$. kuznetsovii showed a homology value of $49 \%$, which justifies a novel species designation for strain $\mathrm{V} 21^{\mathrm{T}}$.

Strain $\mathrm{V} 21^{\mathrm{T}}$ is able to utilize methanol (Table 1), a characteristic it shares with D. kuznetsovii, Desulfotomaculum thermosapovorans, strain TPOSR and strain WW1 only. Methanol utilization by thermophilic sulfate-reducing organisms is a rare characteristic restricted to species of the genus Desulfotomaculum. Strain $\mathrm{V} 21^{\mathrm{T}}$ can utilize fructose, like the moderate thermophiles Desulfotomaculum nigrificans and Desulfotomaculum geothermicum. Glucose utilization has not been described for thermophilic or mesophilic Desulfotomaculum strains and seems to be a unique property of strain $\mathrm{V} 21^{\mathrm{T}}$, though growth is weak. The organism with the closest sequence similarity to strain $\mathrm{V} 21^{\mathrm{T}}$ is D. kuznetsovii. However, this organism produces extremely heat-resistant spores (H. P. Goorissen, unpublished data). The second closest relative, D. luciae, has a limited substrate range, is 
Table 2. Phospholipid fatty acid composition of strain $\mathrm{V} 21^{\top}$ in comparison to some reference strains

Strains: 1, strain $\mathrm{V} 21^{\mathrm{T}}$ (this study); 2, D. thermobenzoicum subsp. thermosyntrophicum DSM $14055^{\mathrm{T}}$ (this study); 3, D. kuznetsovii DSM $6115^{\mathrm{T}}$ (this study); 4, D. australicum AB33 ${ }^{\mathrm{T}}$ (Love et al., 1993).

\begin{tabular}{|c|c|c|c|c|}
\hline \multirow{2}{*}{$\begin{array}{l}\text { Phospholipid } \\
\text { fatty acid }\end{array}$} & \multicolumn{4}{|c|}{ Content ( $\%$ total fatty acids) in: } \\
\hline & 1 & 2 & 3 & 4 \\
\hline $\mathrm{C}_{14: 0}$ & & $2 \cdot 1$ & $2 \cdot 7$ & $0 \cdot 6$ \\
\hline iso- $\mathrm{C}_{15: 0}$ & $68 \cdot 3$ & $55 \cdot 3$ & $49 \cdot 0$ & $48 \cdot 6$ \\
\hline anteiso- $\mathrm{C}_{15: 0}$ & $0 \cdot 2$ & $0 \cdot 2$ & $2 \cdot 9$ & \\
\hline $\mathrm{C}_{15: 0}$ & $1 \cdot 0$ & $6 \cdot 6$ & $9 \cdot 6$ & $0 \cdot 8$ \\
\hline iso- $\mathrm{C}_{16: 1}$ & & $1 \cdot 8$ & & \\
\hline iso- $\mathrm{C}_{16: 0}$ & & $1 \cdot 2$ & $2 \cdot 3$ & $2 \cdot 0$ \\
\hline $\mathrm{C}_{16: 1} \omega 7 c$ & & $1 \cdot 6$ & & \\
\hline $\mathrm{C}_{16: 1} \omega 7 t$ & & $0 \cdot 3$ & & \\
\hline $\mathrm{C}_{16: 1} \omega 5$ & & $0 \cdot 1$ & & \\
\hline $\mathrm{C}_{16: 0}$ & $2 \cdot 5$ & $15 \cdot 7$ & $15 \cdot 5$ & $7 \cdot 4$ \\
\hline iso- $\mathrm{C}_{17: 1}$ & & $0 \cdot 9$ & $0 \cdot 5$ & \\
\hline iso- $\mathrm{C}_{17: 0}$ & $28 \cdot 1$ & $6 \cdot 2$ & $13 \cdot 3$ & $37 \cdot 4$ \\
\hline anteiso- $\mathrm{C}_{17: 0}$ & & $0 \cdot 7$ & $2 \cdot 3$ & \\
\hline cyclo- $\mathrm{C}_{17: 0}$ & & $0 \cdot 4$ & & \\
\hline $\mathrm{C}_{17: 0}$ & & $1 \cdot 1$ & $1 \cdot 8$ & \\
\hline $\mathrm{C}_{18: 1} \omega 9 c$ & & $2 \cdot 3$ & & \\
\hline $\mathrm{C}_{18: 1} \omega 7 c$ & & $1 \cdot 5$ & & \\
\hline $\mathrm{C}_{18: 0}$ & & $1 \cdot 5$ & & $2 \cdot 0$ \\
\hline cyclo- $\mathrm{C}_{19: 0}$ & & $0 \cdot 6$ & & \\
\hline
\end{tabular}

unable to grow on methanol and does not use sulfite. Strain TPOSR, like D. kuznetsovii, produces extremely heatresistant spores and does not grow on sugars. Moreover, the $\mathrm{G}+\mathrm{C}$ content of its DNA is far higher than that of our organism. Strain TPOSR was isolated from an anaerobic bioreactor on propionate, whereas strain $\mathrm{V} 21^{\mathrm{T}}$ was obtained from solfataric sediment.
Sulfite may be inhibitory for micro-organisms, and a sulfite concentration as low as $40 \mathrm{mg} \mathrm{l}^{-1}$ is inhibitory to sulfatereducing organisms (Widdel \& Bak, 1992). Our batchculture experiments with $\mathrm{V} 21^{\mathrm{T}}$, however, showed that sulfite concentrations up to $1.6 \mathrm{~g} \mathrm{l}^{-1}$ did not inhibit sulfidogenesis with methanol (results not shown). The relatively high initial sulfide concentration used in our enrichment experiments may also have increased the selection pressure in favour of sulfate-reducing bacteria. Moreover, an initial sulfide concentration of $5 \mathrm{mM}$ did not inhibit growth or sulfide production by our isolates. Initial sulfide concentrations above $15 \mathrm{mM}$ totally inhibited growth.

On the basis of the physiological differences between strain $\mathrm{V} 21^{\mathrm{T}}$ and all known related organisms, and the results of DNA-DNA hybridization studies, we propose that strain $\mathrm{V} 21^{\mathrm{T}}$ represents a novel species of the genus Desulfotomaculum, namely Desulfotomaculum solfataricum.

\section{Description of Desulfotomaculum solfataricum sp. nov.}

Desulfotomaculum solfataricum [sol.fa.ta' ri.cum. N.L. neut. adj. solfataricum pertaining to solfatares, derived from solfatara (field of hot sulfur springs and fumaroles), referring to the original habitat of the organism].

Cells are straight rods of $1 \cdot 5-2 \cdot 5 \mu \mathrm{m}$ in diameter and $3 \cdot 5-5 \mu \mathrm{m}$ in length, which occur singly and in pairs. Spores are spherical, central or subterminal and distend the cells. Gram stain is negative, but the cell wall structure is typical of Gram-positive micro-organisms. No gas vacuoles are observed. The following substrates are utilized as carbon and energy sources in the presence of sulfate: methanol, ethanol, propanol, butanol, isobutanol, $\mathrm{H}_{2} / \mathrm{CO}_{2}$, acetate, formate, propionate, butyrate, lactate, fumarate, succinate, glucose and fructose. The electron acceptors used are sulfate, sulfite

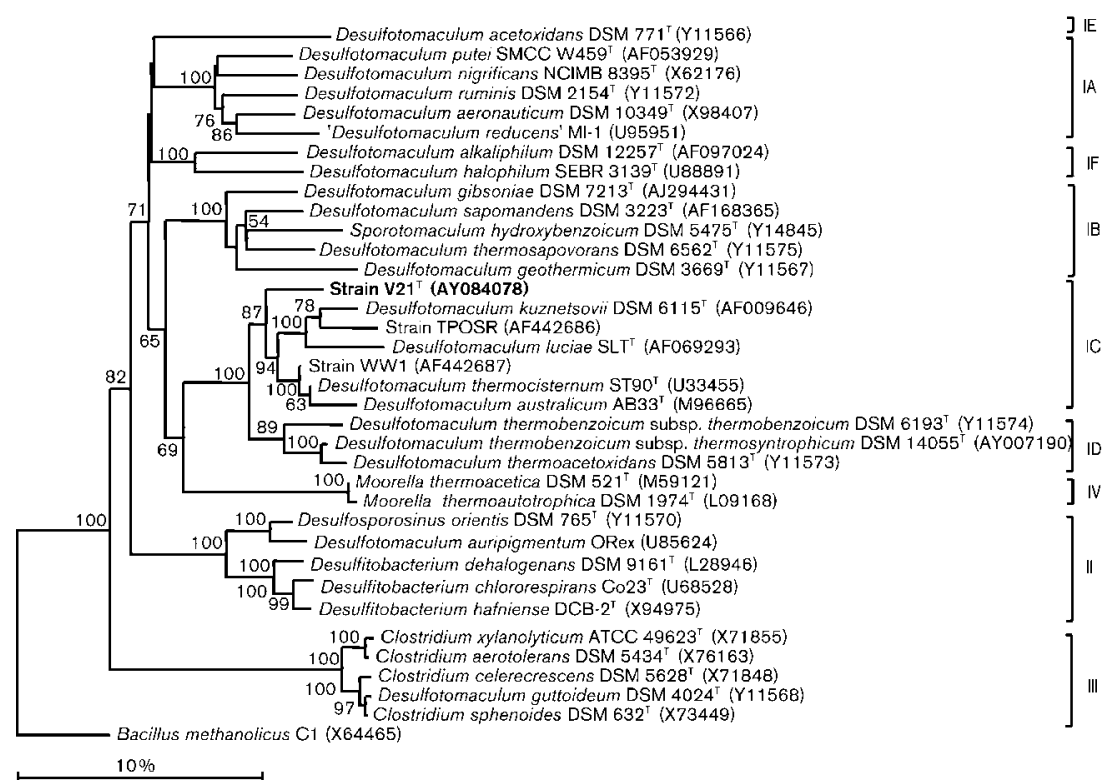

Fig. 1. Phylogenetic tree based on $16 \mathrm{~S}$ rRNA gene sequence comparisons of all validly described species of the genus Desulfotomaculum and some additional strains. The neighbour-joining tree was reconstructed from a distance matrix; bootstrap values above 50 are expressed at the branching points. Cluster designation shown is according to Stackebrandt et al. (1997) and Kuever et al. (1999). Bar, 10 nucleotide substitutions per 100 nucleotides. 
and thiosulfate. Nitrate is not utilized. Initial sulfide concentrations of up to $15 \mathrm{mM}$ are tolerated. Grows fermentatively on lactate. Vitamins are required. The temperature range for growth is $48-65^{\circ} \mathrm{C}$; the optimum growth temperature is $60^{\circ} \mathrm{C}$. The $\mathrm{pH}$ range for growth is $6 \cdot 4-7 \cdot 9$; the optimum $\mathrm{pH}$ is $7 \cdot 3$. The $\mathrm{NaCl}$ concentration range for growth is $0-1 \cdot 5 \%$; best growth occurs without $\mathrm{NaCl}$. Phylogenetically, the species is a member of subcluster IC of the genus Desulfotomaculum.

The type strain of Desulfotomaculum solfataricum is V21 ${ }^{\mathrm{T}}$ $\left(=\mathrm{DSM} 14956^{\mathrm{T}}=\right.$ CIP $\left.107984^{\mathrm{T}}\right)$. Isolated from hot solfataric fields in north-east Iceland. The $\mathrm{G}+\mathrm{C}$ content of its DNA is $48 \cdot 3 \mathrm{~mol} \%$.

\section{ACKNOWLEDGEMENTS}

The authors thank Lubbert Dijkhuizen for his valuable suggestions, Johan Ørlygsson (Akureyri, Iceland) for assistance with sample collection, Manny Nienhuis-Kuiper for DNA isolation and PCR amplification, René Haanstra for 16S rRNA gene sequencing, and Anatoliy Lysenko (Moscow State University) for $\mathrm{G}+\mathrm{C}$ analysis and DNA-DNA hybridization studies. This work was supported by the Technology Foundation STW of the Netherlands Organization for Scientific Research (NWO).

\section{REFERENCES}

Beeder, J., Torsvik, T. \& Lien, T. (1995). Thermodesulforhabdus norvegicus gen. nov., sp. nov., a novel thermophilic sulfate-reducing bacterium from oil field water. Arch Microbiol 164, 331-336.

Boschker, H. T. S., de Brouwer, J. F. C. \& Cappenberg, T. E. (1999). The contribution of macrophyte derived organic matter to microbial biomass in salt marsh sediments: stable carbon-isotope analysis of microbial biomarkers. Limnol Oceanogr 44, 309-319.

Bouchard, B., Beaudet, R., Villemur, R., McSween, G., Lépine, F. \& Bisaillon, J.-G. (1996). Isolation and characterization of Desulfitobacterium frappieri sp. nov., an anaerobic bacterium which reductively dechlorinates pentachlorophenol to 3-chlorophenol. Int $J$ Syst Bacteriol 46, 1010-1015.

Christiansen, N. \& Ahring, B. K. (1996). Desulfitobacterium hafniense sp. nov., an anaerobic, reductively dechlorinating bacterium. Int J Syst Bacteriol 46, 442-448.

Daumas, S., Cord-Ruwisch, R. \& Garcia, J. L. (1988). Desulfotomaculum geothermicum sp. nov., a thermophilic, fatty acid-degrading, sulfate-reducing bacterium isolated with $\mathrm{H}_{2}$ from geothermal ground water. Antonie van Leeuwenhoek 54, 165-178.

De Ley, J., Cattoir, H. \& Reynaerts, A. (1970). The quantitative measurement of DNA hybridization from renaturation rates. Eur J Biochem 12, 133-142.

Elsgaard, L., Prieur, D., Mukwaya, G. M. \& Jørgensen, B. B. (1994). Thermophilic sulfate reduction in hydrothermal sediment of Lake Tanganyika, East Africa. Appl Environ Microbiol 60, 1473-1480.

Fardeau, M. L., Ollivier, B., Patel, B.-K. C., Dwivedi, P., Ragot, M. \& Garcia, J. L. (1995). Isolation and characterization of a thermophilic sulfate-reducing bacterium, Desulfotomaculum thermosapovorans sp. nov. Int J Syst Bacteriol 45, 218-221.

Gerritse, J., Renard, V., Pedro Gomes, T. M., Lawson, P. A., Collins, M. D. \& Gottschal, J. C. (1996). Desulfitobacterium sp. strain PCE1, an anaerobic bacterium that can grow by reductive dechlorination of tetrachloroethene or ortho-chlorinated phenols. Arch Microbiol 165, 132-140.

Gerritse, J., Drzyzga, O., Kloetstra, G., Keijmel, M., Wiersum, L. P., Hutson, R., Collins, M. D. \& Gottschal, J. C. (1999). Influence of different electron donors and acceptors on dehalorespiration of tetrachloroethene by Desulfitobacterium frappieri TCE1. Appl Environ Microbiol 65, 5212-5221.

Goorissen, H. P. (2002). Thermophilic Methanol Utilization by Sulfate Reducing Bacteria. PhD thesis, Groningen University, The Netherlands.

Heijthuijsen, J. H. F. G. \& Hansen, T. A. (1989). Betaine fermentation and oxidation by marine Desulforomonas strains. Appl Environ Microbiol 55, 965-969.

Henry, E. A., Devereux, R., Maki, J. S., Gilmour, C. C., Woese, C. R., Mandelco, L., Schauder, R., Rensen, C. C. \& Mitchell, R. (1994). Characterization of a new thermophilic sulphate-reducing bacterium Thermodesulfovibrio yellowstonii, gen. nov. and sp. nov.: its phylogenetic relationship to Thermodesulfobacterium commune and their origins deep within the bacterial domain. Arch Microbiol 161, 62-69.

Isaksen, M. F., Bak, F. \& Jørgensen, B. B. (1994). Thermophilic sulfate reducing bacteria in cold marine sediment. FEMS Microbiol Ecol 14, 1-8.

Jørgensen, B. B. \& Bak, F. (1991). Pathways and microbiology of thiosulfate transformations and sulfate reduction in a marine sediment (Kattegat, Danmark). Appl Environ Microbiol 57, 847-856.

Kuever, J., Rainey, F. A. \& Hippe, H. (1999). Description of Desulfotomaculum sp. Groll as Desulfotomaculum gibsoniae sp. nov. Int J Syst Bacteriol 49, 1801-1808.

Liu, Y., Karnauchow, T. M., Jarrell, K. F., Balkwill, D. L., Drake, G. R., Ringelberg, D., Clarno, R. \& Boone, D. R. (1997). Description of two new thermophilic Desulfotomaculum spp., Desulfotomaculum putei sp. nov., from a deep terrestrial subsurface, and Desulfotomaculum luciae sp. nov., from a hot spring. Int J Syst Bacteriol 47, 615-621. Love, C. A., Patel, B. K. C., Nicholas, P. D. \& Stackebrandt, E. (1993). Desulfotomaculum australicum, sp. nov., a thermophilic sulfate-reducing bacterium isolated from the Great Artesian Basin of Australia. Syst Appl Microbiol 16, 244-251.

Marmur, J. (1961). A procedure for the isolation of deoxyribonucleic acid from micro-organisms. J Mol Biol 3, 208-218.

Min, H. \& Zinder, S. H. (1990). Isolation and characterization of a thermophilic sulfate-reducing bacterium Desulfotomaculum thermoacetoxidans sp. nov. Arch Microbiol 153, 399-404.

Nazina, T. N., Ivanova, A. E., Kanchaveli, L. P. \& Rozanova, E. P. (1988). A new spore-forming thermophilic methylotrophic sulfate-reducing bacterium, Desulfotomaculum kuznetsovii sp. nov. Microbiologiya 57, 823-827.

Nazina, T. N., Turova, T. P., Poltaraus, A. B., Gryadunov, D. A., Ivanova, A. E., Osipov, G. A. \& Belyaev, S. S. (1999). Phylogenetic position and chemotaxonomic characteristics of the thermophilic sulfate-reducing bacterium Desulfotomaculum kuznetsovii. Microbiology (English translation of Microbiologiya) 68, 92-99.

Nilsen, R. K., Torsvik, T. \& Lien, T. (1996). Desulfotomaculum thermocisternum sp. nov., a sulfate reducer isolated from a hot North Sea oil reservoir. Int J Syst Bacteriol 46, 397-402.

Owen, R. J., Hill, L. R. \& Lapage, S. P. (1961). Determination of DNA-base composition from melting profiles in dilute buffers. Biopolymers 7, 503-516.

Pfennig, N. \& Lippert, K. D. (1966). Über das vitamin $B_{12}$-bedürfnis phototropher Schwefelbakterien. Arch Mikrobiol 55, 245-256.

Pikuta, E., Lysenko, A., Suzina, N., Osipov, G., Kuznetsov, B., Tourova, T., Akimenko, V. \& Laurinavichius, B. (2000). Desulfotomaculum alkaliphilum sp. nov., a new alkaliphilic, moderately 
thermophilic, sulfate-reducing bacterium. Int J Syst Evol Microbiol 50, 25-33.

Plugge, C. M., Balk, M. \& Stams, A. J. M. (2002). Desulfotomaculum thermobenzoicum subsp. thermosyntrophicum subsp. nov., a thermophilic, syntrophic, propionate-oxidizing, spore-forming bacterium. Int J Syst Evol Microbiol 52, 391-399.

Rainey, F. A., Ward-Rainey, N., Kroppenstedt, R. M. \& Stackebrandt, E. (1996). The genus Nocardiopsis represents a phylogenetically coherent taxon and a distinct actinomycete lineage: proposal of Nocardiopsaceae fam. nov. Int J Syst Bacteriol 46, 1088-1092.

Rees, G. N., Grassia, G. S., Sheehy, A. J., Dwivedi, P. P. \& Patel, B. K. C. (1995). Desulfacinum infernum gen. nov., sp. nov., a thermophilic sulfate-reducing bacterium from a petroleum reservoir. Int J Syst Bacteriol 45, 85-89.

Rosnes, J. T., Torsvik, T. \& Lien, T. (1991). Spore-forming thermophilic sulfate-reducing bacteria isolated from North Sea oil field waters. Appl Environ Microbiol 57, 2302-2307.

Rozanova, E. P., Turova, T. P., Kolganova, T. V., Lysenko, A. M., Mitiushina, L. L., lusupov, S. K. \& Beliaev, S. S. (2001). Desulfacinum subterraneum sp. nov. - a new thermophilic sulfatereducing bacterium isolated from a high temperature oil field. Microbiology (English translation of Microbiologiya) 70, 466-471.

Saitou, N. \& Nei, M. (1987). The neighbour-joining method: a new method for reconstructing phylogenetic trees. Mol Biol Evol 4, 406-425.

Sanford, R. A., Cole, J. R., Loffler, F. E. \& Tiedje, J. M. (1996). Characterization of Desulfitobacterium chlororespirans sp. nov., which grows by coupling the oxidation of lactate to the reductive dechlorination of 3-chloro-4-hydroxybenzoate. Appl Environ Microbiol 64, 3800-3808.

Sievert, S. M. \& Kuever, J. (2000). Desulfacinum hydrothermale sp. nov., a thermophilic, sulfate-reducing bacterium from geothermally heated sediments near Milos Island (Greece). Int J Syst Evol Microbiol 50, 1239-1246.

Sleytr, U., Adam, H. \& Klaushofer, H. (1969). The fine structure of the cell wall and cytoplasmic membrane of Clostridium nigrificans demonstrated by means of freeze etching and chemical fixation techniques. Arch Microbiol 66, 40-58.

Sonne-Hansen, J. \& Ahring, B. K. (1999). Thermodesulfobacterium hveragerdense sp. nov., and Thermodesulfovibrio islandicus sp. nov., two thermophilic sulfate-reducing bacteria isolated from a Icelandic hot spring. Syst Appl Microbiol 22, 559-564.

Stackebrandt, E. \& Goebel, B. M. (1994). Taxonomic note: a place for DNA-DNA reassociation and 16S rRNA sequence analysis in the present species definition in bacteriology. Int J Syst Bacteriol 44, 846-849.
Stackebrandt, E., Sproer, C., Rainey, F. A., Burghardt, J., Pauker, O. \& Hippe, H. (1997). Phylogenetic analysis of the genus Desulfotomaculum: evidence for the misclassification of Desulfotomaculum guttoidem and description of Desulfotomaculum orientis as Desulfosporosinus orientis gen. nov., comb. nov. Int J Syst Bacteriol 47, 1134-1139.

Stams, A. J. M., Veenhuis, M., Weenk, G. H. \& Hansen, T. A. (1983). Occurrence of polyglucose as a storage polymer in Desulfovibrio species and in Desulfobulbus propionicus. Arch Microbiol 136, 54-59.

Tardy-Jacquenod, C., Caumette, P., Matheron, R., Lanau, C., Arnauld, O. \& Magot, M. (1996). Characterization of sulfate-reducing bacteria isolated from oil-field waters. Can J Microbiol 42, 259-266.

Tasaki, M., Kamagata, Y., Nakamura, K. \& Mikami, E. (1991). Isolation and characterization of a thermophilic benzoate degrading, sulfate-reducing bacterium, Desulfotomaculum thermobenzoicum sp. nov. Arch Microbiol 155, 348-352.

Trüper, H. G. \& Schlegel, H. G. (1964). Sulphur metabolism in Thiorhodaceae I. Quantitative measurements on growing cells of Chromatium okenii. J Microbiol Ser 30, 225-238.

Utkin, I., Woese, C. \& Wiegel, J. (1994). Isolation and characterization of Desulfitobacterium dehalogenans gen. nov., sp. nov., an anaerobic bacterium which reductively dechlorinates chlorophenolic compounds. Int J Syst Bacteriol 44, 612-619.

Van de Peer, Y. \& De Wachter, R. (1995). TREECON for Windows: a software package for the construction and drawing of evolutionary trees for the Microsoft Windows environment. Comput Appl Biosci 10, 569-570.

Van der Maarel, M. J. E. C., Jansen, M., Haanstra, R., Meijer, W. G. \& Hansen, T. A. (1996). Demethylation of dimethylsulfoniopropionate to 3-S-methylmercaptopropionate by marine sulfate-reducing bacteria. Appl Environ Microbiol 62, 3978-3984.

Weijma, J. (2000). Methanol as Electron Donor for Thermophilic Biological Sulfate and Sulfite Reduction. $\mathrm{PhD}$ thesis, Wageningen University, The Netherlands.

Widdel, F. \& Bak, F. (1992). Gram-negative mesophilic sulfatereducing bacteria. In The Prokaryotes, 2nd edn, vol. 4, pp. 3352-3378. Edited by A. Balows, H. G. Trüper, M. Dworkin, W. Harder \& K.-H. Schleifer. New York: Springer.

Widdel, F. \& Hansen, T. A. (1992). The dissimilatory sulfate- and sulfur-reducing bacteria. In The Prokaryotes, 2nd edn, vol. 1, pp. 583-624. Edited by A. Balows, H. G. Trüper, M. Dworkin, W. Harder \& K.-H. Schleifer. New York: Springer.

Zeikus, J. G., Dawson, M. A., Thompson, T. E., Ingvorsen, K. \& Hatchikian, E. C. (1983). Microbial ecology of volcanic sulphidogenesis: isolation and characterization of Thermodesulfobacterium commune gen. nov. and sp. nov. J Gen Microbiol 129, 1159-1169. 